\title{
The Sino-African Cooperation: A Taiwanese Viewpoint
}

\author{
Ching-Chung Lin ${ }^{1, *}$, Hyacintha O. Faustino ${ }^{2} \&$ Shih-Ju Chan ${ }^{3}$ \\ ${ }^{1}$ Department of International Business, Southern Taiwan University of Science and \\ Technology, No. 1, Nan-Tai Street, Yung-Kang Dist., Tainan 71005, Taiwan \\ ${ }^{2}$ Global MBA, Southern Taiwan University of Science and Technology, No. 1, Nan-Tai Street, \\ Yung-Kang Dist., Tainan 71005, Taiwan \\ ${ }^{3}$ Department of International Business, Kao-Yuan University of Science and Technology, \\ 1821, Chung-Shan Road, Lu-Jhu District, Kao-Hsiung 82151, Taiwan \\ *Corresponding author: Department of International Business, Southern Taiwan University of \\ Science and Technology, No. 1, Nan-Tai Street, Yung-Kang Dist., Tainan 71005, Taiwan. Tel: \\ 1-886-6-253-3131 ext.5100. E-mail: cclin745@stust.edu.tw
}

Received: October 7, 2015 Accepted: January 31, 2016 Published: March 7, 2016

doi:10.5296/rae.v8i1.8400 URL: http://dx.doi.org/10.5296/rae.v8i1.8400

\begin{abstract}
The study is to examine the contemporary trends of the Taiwanese economic involvement in Africa and includes both Taiwanese and Chinese policy toward Africa. Emerging countries are standing side by side in so-called "South-South" cooperation, and are taking advantage of the decreasing image of Western nations following the economic crisis. We are challenging the biased opinion portrayed by the Western press, which is negative toward Asian involvement in African states, and that states the investors (China and Taiwan) are only gaining from their investments. The ambitions on the continent are far from innocent, and nations, such as China are looking to fulfill their demands for natural resources. We intend to emphasize on whether the Chinese presence in Africa is purely resource-based, or if this cooperation is bearing fruit in the future development of African states. The originality of this study lies in its focus on a triangular (China, Taiwan, and Africa) view point of economic interactions and implications because it includes Taiwanese economic involvement in African markets. We hope that these findings, based on sources other than controversial Western articles enable the reader to obtain a better understanding of the current situation, and form their own opinion.
\end{abstract}

Keywords: Africa, China, Cooperation, Economic Growth, Taiwan 


\section{MInstitute"}

\section{Introduction}

In the last decade, recent increasing awareness of African potential has attracted numerous foreign direct investments (FDI) in Africa. As the role of traditional investors, such as France is decreasing, the role of emerging players, such as China, India, and Brazil (CIB) is being reconsidered.

Numerous economic newspapers are capitalizing on African economic development, such as the Economist that in a press article entitled "Africa Rising" stated "Africa now has a chance to follow in the footsteps of Asia" with the same estimated annual growth for 2012 of approximately 6\%. According to Standard Chartered Bank's prediction the average growth rate of Sub Saharan Africa (SSA) was 5.7\% during the last ten years and the African economy will grow at an average rate of $7 \%$ per year over the next 20 years. The Economist stated that five African countries had an average growth rate of $8 \%$ or more in 2011: Chad, Nigeria, Ethiopia, Mozambique, and Rwanda. Moreover, during the past 10 years, six of the world's 10 fastest growing economies were located in SSA, and the fastest growing economy was Angola, with a GDP of 20\% in both 2006 and 2007.

These figures are attracting FDI and are supporting Africa's economic rise. Since the first half of 2009, which was the lowest point of the global economy during the Global Economic Crisis, an increase of $81 \%$ compared to 2008 accounting for $\$ 523$ million were invested in Africa by China (excluding concessional loans).

The following Figure 1 shows that these trends with respect to Chinese imports and exports in Africa from 1995 to 2010, and China's outward investments from 2005 to 2010. We can observe an exponential increase of the total amount of imports and exports. Sub-Saharan Africa benefited by $13.8 \%$ from China's investments.

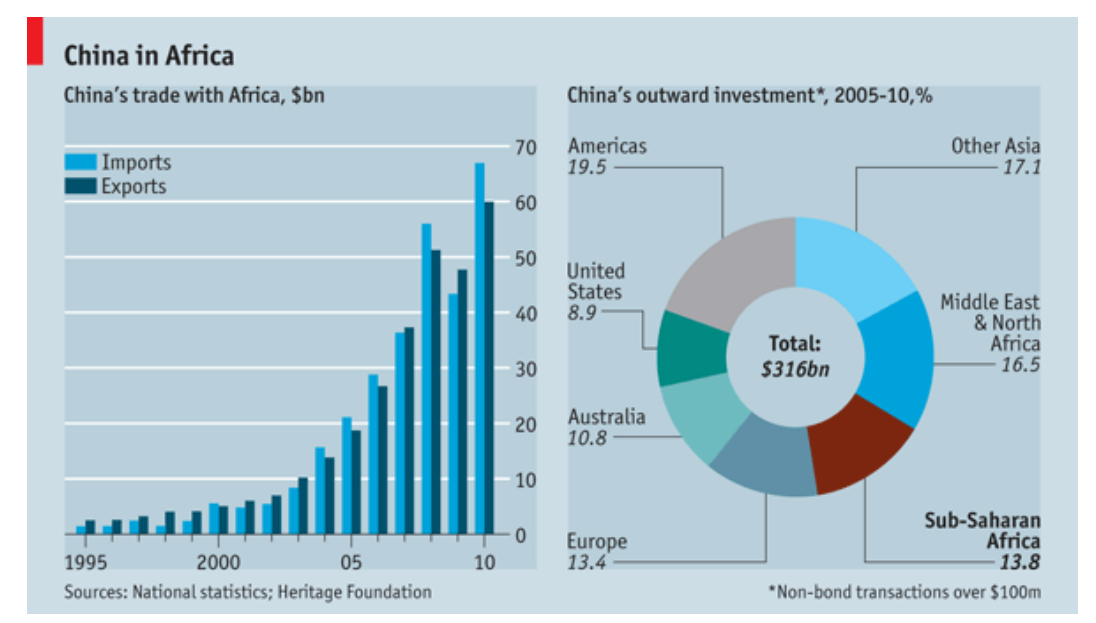

Figure 1. China's imports-exports and outward investments Source: The Economist, April 2011

Demographical data might partly explain this exponential growth rate in Africa, with its 54 
independent countries; it is the second largest continent in the world by population and area, which is $30,221,532 \mathrm{~km}^{2}$. The African continent covers $6 \%$ of the earth's surface and $20.3 \%$ of land surface. In 2009, the African population reached a billion, which is more than $14 \%$ of the world's total population. The actual size of the African continent is often misrepresented on maps. This agrees with the bias that for most people Africa represents despair, conflict, and disease. This image is in the collective mind, and is in the background of alliances or partnerships (Igwe, 2011). In addition to this data, Africa has a significant importance in the global economy because of its natural resources, which are useful for global industrial growth, are undiscovered or barely exploited.

However, for a long period the continent has been colonized by dynamic groups, such as Europeans, and its resources have been exploited without fair regulations. Africa's strengths became its weaknesses. Large quantities of rare raw material are located in areas subject to war, disease, and poverty. Instability and corruption in Africa is more profitable in fulfilling western ambitions.

In politics and on a global scale, these issues cannot be ignored or tolerated any longer. Africa has been and is a major geopolitical and geostrategic axis for Western nations because of factors, such as its population and its numbers of votes in the United Nations. African political leaders, such as Idriss Deby in Chad who has supported China since 2006 or Blaise Compaore in Burkina Faso who is the strongest supporter of Taiwan in African, currently occupy prominent positions in geopolitics. China provides them with the opportunity to express their requirements without political interference in their internal affairs (Marc, 2009). The Chinese embassy stated in Addis Ababa "China never imposes its own will on African countries nor interferes in the domestic affairs of African countries," Because there is no colonial past between Africa and China, although they are seen as new colonists by a minority of Africans and international observers, the truth is that China is a successful capitalist in Africa (Junbo, 2005). In 2010 the total amount of FDI surpassed \$120 billion; increased loans are provided to African countries from China than from the World Bank (The Economist, 2011). The scholar Chris Alden defined Chinese FDI as "Activities ... bolstered by a steady stream of high-profile diplomatic and commercial missions." In 2006 more than 900 Chinese firms where listed in Africa. Currently, China has invested in 48 African countries and built five special economic zones (SEZ), two in Nigeria, one in Ethiopia, one in Mauritius, and one in Zambia

According to the Chinese ministry of education, China offers 1,200 scholarships to African students every year, and offers more than 1,000 training programs for African government officials currently. China has opened 18 Confucius centers across the continent. China has used other methods to strengthen Sino-African cooperation, such as through the FOCAC summit held in Beijing in November in 2006 where the world witnessed the climax of Chinese-African cooperation, with 48 African leaders attending the meeting. In September 2007 Taipei responded with the first African summit with the 5 states that recognized Taiwan as an independent state (Hsiao, 2007). The significant contrast between the two events is a symbol of the ascendancy of China and the decline of Taiwan in Africa. This issue presents particular insights in policies that should to be highlighted. The humanitarian aid-oriented 


\section{Macrothink}

Taiwanese policy significantly differs from both the capitalistic Chinese approach, and in their expectations. Few studies have been conducted on the debate over Taiwanese-African cooperation, whereas there are numerous publications, books, and newspaper articles on Chinese-African cooperation. This has been neglected in recent debates. The numerous and contradicting opinions regarding China in Africa and the lack of research on Taiwan's involvement are the primary reasons for our research into the factors behind this phenomenon. Figure 2 shows that the amount of trade between Taiwan and African countries began to grow only after the 1990s.

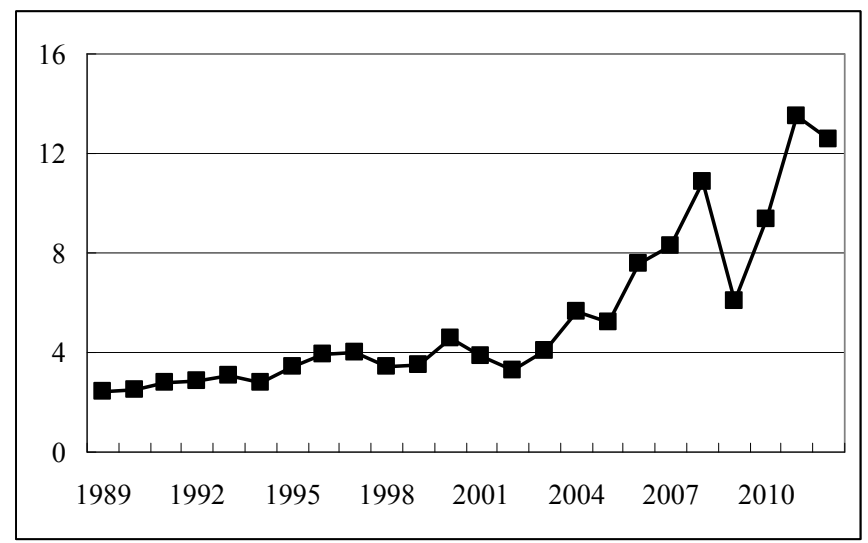

Figure 2. The amount of trade between Taiwan and Africa

Source: Bureau of Foreign Trade, Taiwan (USD billion)

It is clear that Taipei wishes to affirm its links with its African allies. In April 2012 Taiwanese President Ma Ying Jeou visited the African allies of Taiwan for 12 days, officially to strengthen "friendship, cooperation, and exchanges," (Presidential Office of Taiwan, 2012). It was the first visit by a Taiwanese President since the visit of former President Chen Shui-Bian (Chen, 2012). This obviously emphasizes a greater effort to boost diplomatic ties between Taiwan and Africa. Professor Adams Bodomo, Director of the African Studies Department at Hong Kong University stated the importance of Taiwan's African allies vote in the United Nations for Taiwanese international recognition (Broadhead \& Bodomo, 2012).

This paper contextualizes both policies, and considers the nature of Taiwan's current relationship with Africa, including its FDI, business alliances, diplomacy, and humanitarian aid. Journalist David Blair for The Telegraph stated that: "The main motivations behind Chinese investments across Africa appear to be Africa's natural resources. Beijing's options are limited. America and other Western powers have monopolized the world's largest oil reserves. Saudi Arabia and Iraq - with $45 \%$ of the world's oil between them - are in effect closed to China. So the less developed tracks of Africa are an obvious target."

There are also other factors to explain China's growing engagement with Africa, such as access to its local markets, and also the desire to tackle Western countries' preferential trade access in African markets. Brautigham (2010: 65-69) argued that China is providing tools for 
development differently from Western standards. We explore whether the Chinese and Taiwanese FDI and activities in Africa are supporting its development. This study highlights the primary reasons why Chinese and Taiwanese investments are a contribution to African economic growth, and analyzes their drawbacks. Finally, we propose solutions for African governments to capitalize on their own development through regulations, transparency, and good governance; we also explore and analyze to what extend this economic relationship will be profitable in the future.

We propose that African nations can potentially be moderators between Taiwanese and Chinese competition among the international community. In summary the research objectives are as follows: (a) The conceptualization of both policies, (b) The nature of Taiwan's current relationship with Africa, and (c) The differences between Western and Asian types of aid.

\section{Cooperation between Africa and the World}

\subsection{Core Concepts}

\subsubsection{Chinafrica}

When the word Chinafrica is used, it appears to be a callous concept, with numerous limitations. In particular, it is a system, which strongly relies on political relationships to build a commercial bridge between China and Africa (Serge, 2008). It refers to the political, economic, and cultural ties between China and Africa. There are currently 750,000 Chinese immigrants in Africa (Nouck, 2011).

\subsubsection{Francafrica}

Francafrica refers to the relationship France has with its former colonies after independence. It relies on both official and underground networks and is used to denounce the neo-colonial relationship France has with its former colonies and the complex economic and diplomatic relationships between them. François-Xavier Verschave, former President of "Survie" (an association dedicated to denouncing France's crimes in Africa, before, during, and after independence), defines it as "The secret criminality in the upper echelons of French politics and economy, where a kind of underground Republic is hidden from view," (Francois Xavier Verschave, 2006).

\subsubsection{Development}

The term development should be understood in a context of newcomers providing African states with tools for long term development, such as investment in their public infrastructure, health and education sectors, positive spill-over effects from business cooperation, and providing employment to local people.

\subsection{Triangular Dialogue: From aid to development effectiveness}

Francesco Rampa and San Bilal outline in their study that the development of new growth poles in CIB are creating new opportunities for African countries in their relationships with 
external partners. They state that the involvement of new emerging players on the international scene is strongly challenging Africa's traditional partners to reconsider the rules and objectives of their cooperation. Currently, African states have the power to decide what type of partnership they are willing to enter, with an emphasis on the effectiveness of development.

There is a significant necessity in initiating a sincere dialogue with emerging players with new cooperative approaches and impacts, which is a triangular dialogue with effective initiatives. However, the growing role of "South-South" cooperation is increasing negative criticism of traditional aid, and strongly questions its so-called effectiveness. The international community is aware that certain countries cannot appear to be seen as only recipients and others as donors. CIB countries are playing both roles because they are aid recipients and donors simultaneously.

From an African perspective, Europe is typically regarded as a favored partner, because of its colonial past and close ties with the continent. China is perceived to be a reliable partner because of its efficiency in infrastructures and its involvement in various sectors. Brazil is known for its social protection, such as agricultural training, and India for its innovations in the fields of telecommunications and technology transfers to African states. This developmental support model that benefits the African states relies on their comparative advantages through the adoption of multiple strategies on what various partners can offer. Few African countries have a coherently coordinated complementary strategy.

Triangular dialogue is a tool for further collaboration at the country level beginning from specific sectors. It has a greater impact on global decision-making, improves the effectiveness of each partnership approach, and identifies synergies and complementary among partners.

In economic development tactics pursued by emerging players (CIB) in African states, newcomers are often viewed with suspicion by traditional players (European Union, United States); however, Kolbe \& Ritterspach (2011) emphasize one primary issue, which is that policymakers are not active and reactive to design strategies when confronting newcomers in African markets. A clear formulation for a distinct overall response is missing.

The so-called South-South cooperation is offering a fairer alternative model of investment. Western-based media often portray the negatives and drawbacks of cooperation between developing countries. This general climate of distrust and simplistic unnuanced conclusions are causing delays in the formulation of concrete effective policies instead of using a comprehensive strategy for development (Pritchett, 2010).

\subsection{Cooperation between Europe and Africa}

According to a conference report from the Institute of International and Strategic relations, Africa is the first recipient of the European Development Assistance Program. Partnerships between Europe and Africa have a significant importance if we consider the requirements of African populations in natural disasters, wars, diseases or famine (this is the external perspective of Africa). Currently, Africa is a fertile ground for the strategic competition between China, the United States or Europe (Hugon, 2011). The political status of Europe is 
that Africa is not a stable political entity; therefore it is difficult to have a clear policy toward African states because of the ambiguous relationships between France and its former colonies. The Francafrica shadow is deeply rooted, particularly in French speaking African countries. Consequently, the European Union is has problems with new entrants that do not have a similar history or the same interests in Africa.

\subsection{Contribution to Sino-African Research: Chinafrica}

After decades of lack of publicity, China's relationship with Africa has become a popular feature in international media, academic research, and policy engagement. Regarding China's international relationship with Africa, the continent is the negotiation theatre for China's changing status in world affairs. However, Beijing narrow bilateralism with African governments is difficult to manage in African states because they are broadly and multilaterally connected with other external partners and international organizations. A relevant study on China's involvement in Africa is China returns to Africa (Alden, 2005; Large \& Olivera, 2008).

Special economic zones in Africa are contributing to attracting the required capital both nationally and internationally. China is positively contributing to African economic development by transferring its own model of success. Africa is a tool in China's global strategy; this phenomenon was emphasized by the current crisis in Western countries (Davies, 2010). Currently, Special Economic Zones (SEZ) has been formed in African countries, such as Mauritius, Zambia, Egypt, Ethiopia, and Nigeria (with two SEZ). They have strong potential in industrial development, although previous attempts to set up export processing zones have failed (Ancharaz \& Nowbutsing, 2011:12-13) The Forum on China-Africa (FOCAC) cooperation was formed in 2000, since then four successful meetings have been held with the presence of the majority of African leaders. It is currently the institutional mechanism in China-Africa multilateral engagement (Davies, 2010). China's current global strategy partnership with Africa represents one regional and international balance of power; its key factors are the expansion of its distribution channels, the necessity to secure resources and energy assets, and to label Chinese products as Made in Africa (Davies, 2010).

\subsection{Taiwanese-African Cooperation}

Taiwan is one of the main features in China's soft power agenda, and to this extent in the triangular relationships among Africa, China, and Taiwan. Soft power is an important and sensible focus for the leadership of Taiwan (DeLisle, 2010). We could question if whether Beijing is using Africa as a diplomatic weapon in its cross-strait relationships with African states. Taiwan remains concerned regarding the sustainability of its alliance with the United States, because the political and ideological contrast with mainland China is the primary reason to maintain the support of the United States. From this perspective Sino-American unification would be awkward. Through its economic accomplishments, Formosa has more similarities with the United States than any other developed country in the world in transparency, use of law, and respect for intellectual property (DeLisle, 2010).

Moreover, Taiwan's economic accomplishments are examples for East Asia. They are a great 
inspiration to ambitious growing African economies. Taiwan possesses the legal attributes required for statehood according to DE Lisle, including a distinct territory and population accompanied by an autonomous and capable government. Since the loss of its seat in the United Nations in 1971, Taiwan has immersed itself into numerous, extensive engagements through non-governmental organizations (NGOs) in developing countries, such as extensive informal international relationships. China's relationship with Taiwan is an important feature in Africa's triangular relationships with China; the One China policy is the single explicit political conditionality of China's African cooperation. This indicates that the Chinese government has used its African allies in its cross-straits relationships, but has also intruded into African politics. Taiwan's economic relationship with Africa is facilitated with structures, such as the Africa-Taiwan Economic Forum (ATEF), Taiwan-Africa Industry Development Association (TAIDA), and Africa Taiwan Trade Association (AFTA). Since the election of President $\mathrm{Ma}$ in 2008, a transitional phase has begun that places less emphasis on sensible issues and more emphasis on economical ones. The creation of the Taiwan Academies' primary purpose was to rival Beijing's Confucius Institute. Particularly, Taiwan's tactics mirror those of Beijing in numerous manners (DeLisle, 2010).

Most of China's bilateral trade with Africa does not include Taiwan's African allies, except for one of its ex-allies, South Africa, which is the richest country in Africa. In 2007, the amount of bilateral trade reached 4.7 billion Rands, including 3.7 billion in imports of diverse and raw materials and electronic devices to Taiwan. In 2006, Taiwanese investments were $\$ 50$ million, approximately 10 times less than identical investments from the United States (\$486 million) since 1952. The accumulated amount of Taiwanese investments in Africa amounted $\$ 343$ million, compared to the $\$ 6$ billion invested by China. (Marc, 2009)

To show the domains of cooperation between Africa and Taiwan, we examine Burkina Faso, Taiwan's strongest African supporter, as an example: Taiwan provides technical assistance for its agriculture and fisheries; the National University hospital of Ouagadougou was funded through this bilateral cooperation with the collaboration of Taiwanese and Burkinabe physicians (Marc, 2009). The Ouaga 2000 stadium in the capital of Burkina-Faso is a project headed by Taiwan; the vector of this cooperation is the International Cooperation and Development Fund (ICDF). This organization is in charge of the sustainable development and economic progress of partner nations in four areas: humanitarian international aid, financing operations for development projects, technical cooperation through the China Youth Corp, and a program for scholarships. However, this aid is $8 \%$, which is allocated to African states; $75 \%$ is allocated to Asian states. Taiwanese cooperation is modelled on its own aid and development model (Marc, 2009).

\section{Research Design}

Although this study is testing a hypothesis inspired by social conditioning and is not value free, we are aware that Africa is a preferred target because of its large reserves of natural resources; the economic involvement of China and Taiwan cannot be understood outside of this context. The facts are embedded and connected to these social conditions. To conclude, 
this paper does not intend to refute or confirm the hypothesis in its entirety but intends to test to what extent normative assessment can consider as accurate.

The choice of research strategy is oriented on in-depth interviews. The strength of the strategy chosen relies on that it enables us to challenge the existing gap and provides a source of new research questions for further research. Apart from quantitative data, this study involves an analysis of people's impressions on what is currently occurring by providing secondary-source interviews. We are using in-depth interviews of six African diplomats and trade representatives representing African governments in Taipei, and six Taiwanese businesspeople and trade officers with an in-the-field knowledge of African issues. The six major African countries having close relationships with Taiwan and their basic statistics are shown in Table 1.

Table 1. African countries targeted in the research

\begin{tabular}{|c|c|c|c|}
\hline Country & Population & Natural resources & GDP per capita \\
\hline $\begin{array}{l}\text { Burkina } \\
\text { Faso }\end{array}$ & $17,275,115$ & $\begin{array}{l}\text { Manganese, limestone, marble; } \\
\text { small deposits of gold, } \\
\text { phosphates, pumice, salt }\end{array}$ & $\begin{array}{l}\text { USD1 } 500 \\
\text { Agriculture: } 34.7 \% \\
\text { Industry: } 23.3 \% \\
\text { Services: } 42 \%\end{array}$ \\
\hline Gambia & $1,840,454$ & $\begin{array}{l}\text { Fish, clay, silica sand, titanium } \\
\text { (rutile and limonite), tin, zircon }\end{array}$ & $\begin{array}{l}\text { USD2 } 100 \\
\text { Agriculture: } 26.7 \% \\
\text { Industry: } 17.4 \% \\
\text { Services: } 55.9 \%\end{array}$ \\
\hline Swaziland & $1,386,914$ & $\begin{array}{l}\text { Asbestos, coal, clay, cassiterite, } \\
\text { hydropower, forests, small gold } \\
\text { and diamond deposits, quarry } \\
\text { stone, and talc }\end{array}$ & $\begin{array}{l}\text { USD5 } 200 \\
\text { Agriculture: } 8.2 \% \\
\text { Industry: } 46.9 \% \\
\text { Services: } 44.9 \%\end{array}$ \\
\hline $\begin{array}{l}\text { Sao Tome \& } \\
\text { Principe }\end{array}$ & 183,176 & Fish, hydropower & $\begin{array}{l}\text { USD2 } 000 \\
\text { Agriculture: } 15 \% \\
\text { Industry: } 24.4 \% \\
\text { Services: } 60.6 \%\end{array}$ \\
\hline Nigeria & $170,123,740$ & $\begin{array}{l}\text { Natural gas, petroleum, tin, iron } \\
\text { ore, coal, limestone, niobium, } \\
\text { lead, zinc, arable land }\end{array}$ & $\begin{array}{l}\text { USD2 } 600 \\
\text { Agriculture: } 35.4 \% \\
\text { Industry: } 33.6 \% \\
\text { Services: } 31 \%\end{array}$ \\
\hline South Africa & $48,810,427$ & $\begin{array}{l}\text { Gold, chromium, antimony, coal, } \\
\text { iron ore, manganese, nickel, } \\
\text { phosphates, tin, rare earth } \\
\text { elements, uranium, gem } \\
\text { diamonds, platinum, copper }\end{array}$ & $\begin{array}{l}\text { USD1 } 1000 \\
\text { Agriculture: } 2.5 \% \\
\text { Industry: } 31.6 \% \\
\text { Services: } 65.9 \%\end{array}$ \\
\hline
\end{tabular}

Source: CIA World Factbook, June 25, 2012 
Finally, this paper includes and quotes scholars whose contributions to the research are considered significant. We have attempted to ensure the validity of the data by constantly examining new information so that our data could be as current as possible. To reach these research goals, a series of in-depth interviews have been conducted in Taipei and Tainan. Among the entities interviewed are trade officers, Taiwanese businesspeople, and African diplomats in Taipei. The questions asked to the respondents are as follows:

(a) What is the role of your organization?

(b) What is the African policy on Taiwan?

(c) What is the plan in the next 5 to 10 years?

(d) Why are Taiwanese firms willing to invest in Africa?

(e) What is the driving force of their investments?

(f) Why do larger firms lack ambition to invest in Africa?

(g) What is the pattern of trade investment of Taiwanese firms in Africa?

(h) How is the Taiwanese government supporting this enterprise abroad?

(i) Are the regulations easy?

(j) What is Taiwan's contribution and social responsibility in doing business in less developed countries?

(k) What are the principal characteristics and trends of Taiwanese private investments and Taiwanese enterprises in Africa?

(1) Who or what is driving these investments and the outward expansion of Chinese private enterprise?

(m) What are the benefits of this growing private sector presence in African development?

\section{Research Results}

The interview responses were based on the informants' experiences, either actual or by observation and perceptions. We wish to highlight the empirical data in the results, which is a transcript of the interviews with the informants, in addition to an interpretive and prescriptive analysis based on the collected data.

The answers were interpreted and analyzed in the following detailed discussion. Among the entities interviewed, certain key issues were thought to be a priority for both parts. There is a growing interest in Taiwanese firms in investing and expanding in Africa, such as in Nigeria where more than 30 Taiwanese SMEs have a registered business.

The responses were interpreted and analyzed in a detailed discussion following six issues: Taiwanese policies on Africa, the driving force of Taiwanese SME investments in Africa, the 
lack of ambition from MNEs to enter African markets, Taiwanese social responsibility in doing business in Africa, eventual support from government, and major obstacles faced by Taiwanese firms in Africa. The entire process was conducted from an African development perspective.

\subsection{Taiwan's Foreign Policy in Africa}

One of the interviewees informed us that the six Taiwanese partners were members of the African group; those country representatives occasionally met to discuss several issues regarding their ties with Taiwan. Among the interviews, the outcome for this issue is that there is clear ambition from the Taiwanese government to clearly define its position with its allies and its economic African partners, which are not strictly limited to those six countries. For the majority of respondents there are few or no links between Taiwan's current status in the international scene and the internationalization of its SMEs. Therefore, there are existing NGOs, such as ATEF, or TAITRA, which is the chamber of commerce Taiwan External Trade Development Council (ETDC) and are in charge of linking Taiwan with Africa, for the first one, and with the world, for the second. After decades of intensive aid in areas, such as agriculture and medical care, Taiwan currently emphasizes the training of local people to create sustainable development. The Taiwanese government's approach is more pragmatic; it aims to achieve quantifiable results in Africa by "teaching people how to fish instead of given them fish."

\subsection{The Driving Force of Taiwanese SME investments in Africa}

For the two Taiwanese businessmen interviewed for this research, it appears that one significant motivation to invest and establish factories in Africa is the financial crisis currently faced by Western economies. Africa also has great potential because of its large population (approximately 1 billion) and its increasing economies, which are increasing its citizens' purchasing power.

It also appears that certain countries have near transparency and good governance, which permits business registration to be accomplished more quickly; however others do not. Overall, it appears that for Taiwanese businessmen Africa is largely unexplored but few are willing to risk or invest their own private capital because they are unsure of the outcome.

Because goods are produced and made in Africa, this permits them to penetrate the American market without trade barriers through the African Growth and Opportunity Act (AGOA). The interviewees stated that most Taiwanese companies are focused on South East Asian markets and Western countries and few are focused on African markets.

Taiwanese firms involved with Africa have clear goals, which are to assist their industrial development and transfer Taiwanese technological skill sets to developing nations. In addition, we can observe that there are no limits in business. One interviewee stated that: "The priority is to promote trade and investments in potential markets where there are more chances and opportunities for Taiwanese to expand to, such as Ghana, Kenya, Botswana, Mozambique, Uganda, Ethiopia, and Angola. We have connections everywhere in Africa." 


\subsection{The Lack of Ambition from MNEs to Penetrate African Markets}

The Chairman of TAIDA stated, "I often complain to Taiwanese CEOs because they don't see the potential of Africa. They are focused on ready-to-sell markets. In the case of Africa it is too far and people don't understand it."

We can observe that larger firms, which have the potential to heavily invest in African markets, are reluctant; they do not want to take risks, send their best managers, and spend money when the outcomes are uncertain. For one African official it is the so-called "leadership problems," or the corruption and the political instability, which must be a priority to solve.

Moreover, the Managing Director of AFTA said, "SMEs are looking to invest in their local markets. Those firms have never been to Africa, and they don't know anything about it. It is easier and faster in terms of returns on investments; why should they take the risk to invest into uncertain markets and economies?" She also stated, "Big groups have global links so Africa is not a priority for them." It appears that Taiwan is actively involved in the sustainable development of the African nations it is assisting because it was once also a recipient of aid from the United States. Richard Lin said, "When I was a kid 40 years ago Taiwan was not more developed than Africa, look at what we have achieved in half a century. We can now pass our knowledge to other developing nations." According to him MNEs do not lack ambition to go to Africa. They lack information and transparency. Africa is not a prepared market for big firms, and there is also a lack of international managers. Mangers do not wish to travel to Africa; they wish to remain in Taiwan. Businesses are too expensive, and Africa is an uncertain investment.

\subsection{Taiwan's Contribution and Social Responsibility in Conducting Business in Africa}

The Managing Director of AFTA stated, "One day I had a meeting in South Africa with one of Mandela's relatives. I asked him: What do you need? He told me, 'In Africa we need everything." Taiwan is more focused on the implementation of assistance programs based on a model that requires local people to engage in the program themselves under the guidance and supervision of Taiwanese consultants. These examples include: healthcare, agricultural training, and scholarships allocated to African students in Taiwan.

Currently, more than 20 projects are under implementation in Africa. Through its overseas volunteer service Taiwan is also demonstrating its soft power. Since 1996, nearly 500 volunteers have travelled to 30 nations. The program's main purpose is to improve diplomatic relations by encouraging the participation of Taiwan's general public in international cooperation and developmental affairs. One of the interviewees shared the story of the transfer of his chalk factory from Tainan to Banjul in the Gambia. Because one of its main clients are the schools from French-speaking countries in Africa, he save on shipping costs, provided employment for the local workforce in Gambia, and can engage in more potential markets. 


\subsection{Eventual Support from Government}

The Taiwanese government is supporting SMEs in expanding in Africa but conditions are different for countries with diplomatic ties than for those without. With the help of ICDF, which belongs to MOFA, a potential investor can apply and receive financial support to $60 \%$ of their total investment with a low interest rate. For countries without diplomatic ties with Taiwan, investors cannot rely on state aid because there are no official Taiwanese entities in those countries to protect their citizens.

\subsection{Major Obstacles faced by Taiwanese Firms in Africa}

One of the primary barriers to trade between Taiwan and Africa is the distance: "It is too far and time consuming"; another uncovered issue is the visa requirements in countries with diplomatic ties with mainland China, which are nearly all countries. Market uncertainty is also a critical debate because it involves risks for businesses. AFTA recently opened a Moto spare-part factory in Egypt, and they are concerned regarding the political situation in Egypt. These are certain reasons why developing economies are a preferred choice for Taiwanese organizations.

From the perspective of African officials, they agree that they can improve their infrastructure, water supplies, and energy use, and the transparency of their tax systems to encourage more businesses to expand into their markets. Corruption and trust issues are heavy drawbacks.

African diplomats are happy and grateful for the cooperation scheme that Taiwan is proposing them; their effects are quantifiable in education, health care, and infrastructure. Money is not only allocated by the Taiwanese government to ensure that its allies support Taiwan as required (in opposition with dollar diplomacy that has often been observed in the past). Proper monitoring of each activity and project that has been introduced occurs. Taiwan is guiding its African allies to good governance and transparency habits. The Taiwanese businesspeople that were interviewed were frequently unhappy relative to the difficulties linked with the introduction of new industries in Africa. They appear to have strong social responsibility, and they are willing to help Africa reach industrialization. Regrettably, Africans are not prepared to fully embrace industrialization. For example, Africans would prefer to purchase finish products from European markets but they are reluctant to invest in skills. Taiwanese industries are prepared to share and transfer their technologies to them but profits are not their primary motivation; they are not expecting immediate returns on their investments. Larger Taiwanese firms are also not motivated to invest in African markets because of the risks involved, instability, and lack of knowledge and transparency in the markets potentialities. In 2003, the ATEF, an NGO, was established with the full support of the Taiwanese government. Its main purpose is to build an economic bridge.

\section{Conclusion}

The research questions in this study are: (a) Although the Chinese approach is considerably different from the Western-style approach, what is the Taiwanese approach in Africa? (b) Is 
Beijing using Africa against Taiwan as a diplomatic weapon in its cross-strait relationships?

We initially expected that this statement would be true: "African states do not invariably gain from the Sino-African relationship; the cooperation is primarily positive for China and Taiwan." The study of political issues could result in further rewarding results. Time constraints, however, did not permit such a broad analysis of this topic; in the future, we wish to continue furthering this research by exploring it with a more concentrated focus. The purpose of this research was to uncover the typical trends behind Taiwanese and Chinese economic involvement in African states.

First, we analyzed current trends of newly developed economies active in the involvement in Africa, and analysed its implications in African economic development. Through our research, it appears that there are no signs of economic dominance and that Taiwanese cooperation is significantly different from Chinese policies. Taiwan is seeking international recognition but mainland China wishes to expand its worldwide markets. We examined whether Taiwan provides these countries with a new type of support for development or whether it only exploits their economies. The results show that Taiwan provides its African partners with several tools for long-term development.

Second, we assessed whether Beijing is using Africa as a diplomatic weapon against Taiwan. The results are variable but are primarily negative because African nations are not involved in the political issues between Taiwan and China. The positive effects of Taiwanese involvement in Africa have constituted a challenge to our initial hypothesis that states that only Taiwan is benefiting from the relationship. The positive effects include the investment and financial assistance directed to country infrastructures and construction sectors, and the support in health, education, and technical training to provide future job opportunities to African students. Non-political interference and primary business-oriented focus is in opposition to the Western-style approach. This innovative approach can be called a new type of support for development. Because of this that portion of the hypothesis has been proven to be untrue, and our understanding of the issue has been changed. Chinese business practices in Africa are facing core negative drawbacks, and there is evidence of social tension and dissatisfaction with Chinese business practices. These results are the shared responsibilities of Chinese exploitative strategies and the inefficiencies of African governments that failed to regulate their practices. We conclude that the Taiwanese economy is emerging as a new supporter in development. Because the phenomenon is occurring in a reality of corrupted African governments and is purely focused on business, this is causing scepticism in the West; The West is falsely portraying Asian economies in a negative light. The extent new players in Africa exploit and dominate African economies is because African government permit them to. Africa has a bright future, and will be able to use these opportunities for its long-term benefits in the future. 


\section{References}

Alden, C. (2005). China returns to Africa. Survival: Global Politics and Strategy, 47(3), 147-164

Ancharaz, V., \& Nowbutsing, B. (2011). The developmental impacts of Chinese zones in Africa: Insights from a case study of the Jin Fee zone in Mauritius, Trade Negotiation insights, 10(3), 12-13,

Broadhead, I. \& Bodomo, A. (2012). Taiwan President Wraps Up Tour of Africa. Voice of America. Retrieved from http://www.voanews.com/content/taiwan-president-wraps-up-tour-of-africa-147888875/1 80136.html

Davies, M. (2010). How China Is Influencing African Development.

DeLisle, J. (2010). Soft Power in a Hard Place: China, Taiwan, Cross-Strait Relations and U.S. Policy. Foreign Policy research institute, 493-524. http://dx.doi.org/10.1016/j.orbis.2010.07.002

François Xavier Verschave. (2006). Retrieved from http://survie.org/francafrique/article/defining-francafrique-by-francois

Hsiao, E. (2007). Taiwan-Africa summit deepens relations. Retrieved from http://www.taiwantoday.tw/ct.asp?xItem $=24647 \&$ CtNode $=428$

Hugon, P. (2011). Les relations entre 1' union européenne et le continent africain. Institut des relations internationales et strategiques (IRIS).

Igwe, U. (2011). Rethinking engagement with Africa: An African perspective. Trade Negociations Insight, 10(3), 16-17,

Junbo, B. J. (2007). China in Africa: From capitalism to colonialism. Asia Time, 2005-2006.

Kolbe, J., \& Ritterspach, K. (2011). Emerging donors in Africa! What strategy for U.S. engagement? Trade Negociations Insight, 10(3), 5-6.

Large, D., Alden,C., \& Soares de Olivera. (2008). China returns to Africa. Conference paper From Non-Interference to Constructive Engagement? China's Evolving Relations with Africa: the case of Sudan.

Marc, A. (2009). Les relations taiwan - afrique!: entre continuité et rupture, 267-283. Geostrategiques n25 10/09, Geopolitique des Afriques Subsahariennes

Nouck, L. N. (2011). China's promises to Africa. African Journal of Political Science and International Relations, 5(July), 367-370.

Pritchett, A. G. (2010). Book Brief: The dragon's gift: the real story of China in Africa. American Foreign Policy Interests, 32(3), 201-202. http://dx.doi.org/10.1080/10803920.2010.487712. 


\section{Macrothink}

Research in Applied Economics

ISSN 1948-5433 2016, Vol. 8, No. 1

Presidential Office of Taiwan. (2012). President Ma First visit to its African allies. Retrieved from http://english.president.gov.tw/Default.aspx?tabid=1395

Serge, M. B. (2008). La Chinafrique: Pékin à la conquete du continenent Noir. Paris.

The Economist online. (2011). The Chinese are coming...to Africa (online article).

Chen, Wei (2012). Ma embarks on 12-day trip to Africa. Retrieved from http://www.taipeitimes.com/News/front/archives/2012/04/08/2003529788

\section{Copyright Disclaimer}

Copyright for this article is retained by the author(s), with first publication rights granted to the journal.

This is an open-access article distributed under the terms and conditions of the Creative Commons Attribution license (http://creativecommons.org/licenses/by/3.0/). 